\title{
Green ICT at Higher Education Institution: Solution for Sustenance of ICT in Future
}

\author{
Kavita Suryawanshi \\ Dr. D.Y.Patil Institute of MCA \\ Savitribai Phule Pune University, Pune, \\ Maharashtra, India
}

\author{
Sameer Narkhede \\ School of Management Studies \\ North Maharashtra University \\ Jalgaon, Maharashtra, India
}

\begin{abstract}
There is necessitating willingness to protect our natural world from environmental issues for current and future generations. Green Information and Communication Technology is a pioneering approach of using ICT related to the environment protection and sustainability of ICT in future as well as consists of practices to achieve corporate social responsibility by minimizing carbon footprint, ICT waste and by conserving energy. This paper analyzes the rational of Green ICT in education and finds critical success factors for Green ICT implementation based on survey of selected educational institutes and interviews with academic key experts in India. This paper presents the national mission for Green India derived from detailed analysis of the pertinent literature. This study identified seven critical success factors which are essential for sustainability of ICT in future.
\end{abstract}

\section{General Terms}

Green Technology

\section{Keywords}

Information and Communication Technology (ICT), Green ICT (GICT), Critical Success Factors, Higher Education Institution, Sustenance of ICT.

\section{INTRODUCTION}

Now a day Green technology and sustainability are one of the most widespread concerns. Tremendous climate change in recent years is one of the obvious pointers that the earth is sick. It is very much necessary to save the environment and ultimately the world. In spite of the benefits that ICTs provide, they likewise help environmental problems, consuming incredible amounts of electricity and creating carbon dioxide emissions [1]. According the literature concerning the environment impact of ICT's, ICT is considered part of the environmental problem and at the same time part of solution. It is important to comprehend that ICT's can reverse the current situation and that can constitute an effective vehicle for sustainable development [2]. Currently the prime challenge facing the environment is global warming, caused by carbon emission [3].

A dawning era of innovation in green computing is bringing the promise of a healthier planet. Green or Eco sustainability is the capacity of one or more substances, either separately or on the whole, to exist and flourish for long time allotments, in such way that the presence and prospering of different collectivizes of elements is acceptable at recognized levels and in known frameworks [4].Green Technology is a nonprofit endeavor designed to update government efforts toward sustainability, providing a forum in which government officials can communicate with those in the private sector who are developing and distributing green technologies [5].

Being environment friendly is always helpful for the economic condition and civilization. There is no harmful consequence of adopting Green ICT practices, as a result no regrets. It saves the asset of the country by and large. It is presently high time academicians ought to begin sparing fuel sources and energy for the future eras along with saving money and assets for them [6].Use of ICT in education is cause of carbon dioxide emission, high energy consumption and hazardous waste production [7]. Most of the educational institutes attempt to write-off computers after predetermined period of time which led creation of e-waste. These pressure directed higher education institution to implement Green ICT in order to reduce energy utilization, carbon dioxide emissions, hazardous e-waste, energy cost and to boost recycle and reuse. In addition savings is attained by minimizing the wastage of computational facility [8]. With the increase in the number of institution offering higher education, green ICT practices at institution has ended up key factor to attain cost effective results and corporate social obligation. The colleges and universities are obtaining more sustainable approaches to ICT use [9].Green ICT has been a dynamic research area which ponders a productive utilization of IT equipment's. It is basic need to teach all stakeholders of education institutions to think green for sustenance of ICT, society and globe. The green ICT practices are lessening greenhouse gas emanations however by keeping utilization of ICT as it is in our everyday life. This study covers the sustenance of ICT for saving energy for this technology and along with preventing mother Earth from hazardous carbon emissions which is significant cause of global warming.

This paper rigorously reviews the literature available on Green ICT and the researchers identified critical success factors for Green ICT implementation at education institutions. The structure of paper is as follows. Initially, the researchers reviewed Green ICT concepts and its global view. Secondly the researchers have presented the Green ICT in education sector from India perspective. A discussion on the analysis of critical success factors was followed by a conclusion.

\section{RELEATED WORK}

Sustainable presence of human and different creatures on Earth requires that our future ICT advances must be intrinsically sustainable both by nature and in utilization [10].To eliminate environmental problems like climate change we have to adopt green ICT practices effectively.

\subsection{Green ICT}

Current studies on ICT characterize it at various viewpoints and perspectives. Definitions made and proposed by Molla [11], Mingay [12], and Murugesan [13] concentrate on industry and business viewpoints regarding resource utilization, e-waste generation and carbon dioxide emissions. Jussi Ahola [14] defines it as sustainable ICT aiming to reduce impact of ICT on environment. Cosmo [15], Unhelkar[16] invented it as individual or collective, efficient and effective efforts with no impact on surroundings. 
Based on rigorous pertinent literature review this study confirms and expressed it as, "Green ICT is an pioneering way of using ICT that consists of policies and practices which deal with environment sustainability by minimizing carbon footprint, ICT waste and by optimizing energy consumption and by conserving natural resources for cost effectiveness, sustenance of ICT and to save planet".

\subsection{Global Perspective of Green ICT in Education}

The education institutions are alerting as well as instructing and preparing the society to tackle environmental issues and to adopt environmental sound practices in their approach of using ICT.UNESCO aims to ensure that all countries, both developed and developing, have access to the best educational facilities necessary to prepare young people to play full roles in modern society and to contribute to a knowledge nation [17]. With the expanding realization of environmental issues around the world, institutions are turning to green ICT initiatives. Green ICT ensures the benefits only. The UK is one of the first countries to focus on Green ICT in form of governmental policies and put pressure on UK Higher Education Institutions to implement Green ICT [18].The UK has a generally speaking to decrease Greenhouse gasses by $26 \%$ by 2020 and by no short of what $60 \%$ by 2050 .Indonesia has designed Green ICT National Policy Roadmap and also organized 10 conferences on Green ICT in the year 2010. Indonesia declared emission reduction target of $26 \%$ from business as usual by 2020 and this can be increased to $41 \%$ with enhanced international assistance [19].

The Dutch Higher education institutions are following Green ICT practices by building a Green ICT community of more than 300 members which stimulate and help their universities to work on green (ICT) issues. They are following various Green ICT practices like Mobile workplace, Flexible office/classroom spaces, Distance learning/teaching, minimize student commuting etc.[20]. RMIT University, Australia categorizes four general pillars of Green ICT like Life cycle, End user, Enterprise and Enablement [21]. Australian Government ICT Sustainability plan 2010-2015 which outlines strategies and actions for its agencies to lower greenhouse gas emissions 605 of 2000 levels by 2050 [22].

The government has a significant role to play in promoting green ICT policies and initiatives against environmental concerns including Greenhouse gas (GHG) emissions reductions. Malaysia national Green Technology Policy suggested five strategies to enhance green technology research and development [23].

\section{GREEN ICT IN EDUCATION SECTOR: INDIA VIEW}

India actively promotes the use of information and communication technologies in education sector. Higher education in India has witnessed an impressive growth over the years. The number of higher educational institutions (HEIs) has increased from about 30 universities and 695 colleges in 1950-51 to about 700 universities and 35,000 colleges as per a recent University Grant Commission report. With an annual enrolment of above 25 million, India is today ranked as the third largest higher education system in the world after US and China [24].The national policy for integrating ICT into education by MHRD is laid down in the Five Year Development Plan.ICT is playing vital role in education [25]. US Energy Information Administration publishes international energy statistics reveals that India is now the world's third biggest emitter of carbon dioxide [26]. The global E-waste generation is growing annually at 40 million tones and in next 10 years India's e-waste is likely to grow by 18 times [27].Concerning higher education institutions, the learners and academicians have extended the use of ICT as a part of their consistent life. Each living individual should come to be Green pioneer for social change and saving mankind from natural defilement. Green ICT helps education organizations to realize social profits like enhanced image, higher reputation and trustworthiness among all stakeholders [28].India's spending on green IT and sustainability initiatives will double from $\$ 35$ billion in 2010 to $\$ 70$ billion in 2015 , according to a report by research and advisory firm Gartner.

Indian has a national mission for Green India.HCL was the first Indian company to have more than $50 \%$ of its range of laptops and desktops Energy Star 5.0 compliant.HCL is the world's 3rd Greenest ICT Company, according to the latest Greenpeace Rankings [29].There is necessity to raise community awareness about Green ICT practices and opportunities and also set fundamentals and national policies for Green ICT. Government of India ministry of Environment and Forests (2011) have developed national mission for Green India under the national action plan on climate change (NAPCC). They have presented tentative action plan for implementations of the Green India mission [30]. India's National Mission on Enhanced Energy Efficiency (NMEEE) has identified approaches to unlock energy efficiency opportunities and have goal of Co2 emission mitigation of 98 million tons per year by $2014-2015$ [31].

\section{ANALYSIS AND DISCUSSION}

The analysis of critical success factors for Green ICT implementation at educational institutions discussed in this section are based on the data collected from survey questionnaire contained 35 questions, developed on the basis of pertinent rigorous literature review and interviews with academic experts like Director or Deans of selected higher education institutions in India.

\subsection{Green ICT Critical Success Factors}

The existence and importance of each critical success factor in the implementation of GICT is established empirically on the basis of review and interviews with key academic experts. Green ICT encourages and supports greener behavior by the faculties, staff members, students and admin people. By various means, including awareness campaigns and ongoing education, and in some cases legislation, the whole culture of education institutions changed. Finally, by implementing Green ICT, education institutions ensure the sustainability of the ICT resources. This study has investigated the ways in which educational institutes can reduce, reuse and recycle infrastructure. The Green ICT practices like IT equipment recycling, less printing, end-user PC power management, Green ICT committee formation, use of thin client model and cloud computing ,buying of energy certified equipment, use of renewable energy sources for ICT are followed by the higher education institutions to achieve cost effective solution [28]. Regardless of the initiatives and GICT practices, the factors that most significantly determine the success likelihood of green ICT implementation in education sector are as follows:

\subsubsection{Optimum Utilization of Resources:}

This factor ensures reduction in carbon footprint through optimal and efficient use of IT equipment's as well as proper disposal of hardware and its hazardous components. Green 
ICT proposes to utilize energy effective supplies and diminish energy cost. Optimum utilization of ICT resources during the usage lead to the conservation of natural resources which in turn ultimately save environment.

\subsubsection{Stakeholder's Involvement:}

This factor requires self-motivation and rational for adoption of Green ICT by all stakeholders of education institution like staff, faculty, students and top management people. Green ICT is neither a product that you can establish and forget about it nor a tool which you can implement during night [32]. It is set of practices which all stakeholders of education institutions need to follow on regular basic to achieve sustenance of ICT in future. Each one of us has to actively followed green ICT practices in our daily life to accomplish minimal or no impact on the environment. The study shows that many of the institution's stakeholders are motivated in their approach of using ICT resources.

\subsubsection{Renewable Energy:}

Why to depend upon the standard electrical energy source to power your ICT equipment when you can use alternate renewable energy sources like wind power, solar energy, biomass etc. As ICT is playing vital role in education, reduced energy cost has to be urging by all education institutions because electrical energy is produced by using scared natural resources. With the rising cost of electric energy, more ICT equipment translates to higher costs of power consumption. So if ICT products continue consuming the power they have been consuming, it could have serious implications. Most of education institutions are planning for renewable energy sources for ICT to reduce energy cost and for successful GICT implementation.

\subsubsection{Energy Conservation:}

Irrespective of type of energy to be used, it must be conserved for future use. It's our prime responsibility to save natural resources for future generation as well as for sustenance of natural resources. Each member of educational institution must be habitual to switch off ICT equipment when not in used to conserve energy for future use. It ultimately achieved the objective of cost reduction. It is seen that most of the institution is having the culture of use of energy as per need.

\subsubsection{Institutional Policy:}

This factor plays very important role in the success of GICT implementation. Most of the institutes having their own Green policy play very active in achieving corporate social responsibility. Credit points or awards of different categories are allocated to motivate faculties and students as per their approach of using Green ICT practices. The many institutes have well designed policy for green procurement, green disposal and green use. All most all institutions is having their Reuse, Recycle and Refurbish policy as green approach to ensure $100 \%$ recyclability and safe disposal of institution e-waste, through a responsible recycler.

\subsubsection{Green ICT Committee Activities:}

Though the institution has Green policy as per the vision and mission of the institute, the establishment of Green ICT Committee is prime factor towards the success of Green ICT implementation at institution. GICT practices are closely monitored and controlled by this committee as well as assessment of objectives is carried out successfully. This committee is responsible to increase GICT practices awareness among all the stakeholders of the institute. The financial support is critical factor for the success of GICT implementation in education institutions. The management perform vital role in sanctioning the budget for the same.

\subsubsection{Legislation:}

The study observed that strict government legislation is crucial for successful implementation of Green ICT in education sector. There are some legislation which is followed in green design, use and disposal of ICT equipment like Restricted materials as per European Union Directive 2002/95/EC - "Restriction on the use of certain Hazardous Substances" (RoHS), disposal of electrical equipment as stated by European Union Waste Electrical and Electronic Equipment Directive (2002/96/EC), Packaging and Packaging Waste $(94 / 62 / E C)$ calling for the abolition of toxics in packaging [33]. These legislations help to achieve greener environment and ultimately sustenance of ICT. Government has needed to organize awareness campaign to increase consciousness about green ICT practices among the entire lifecycle of society for saving mankind from environment pollution.

\section{CONCLUSION}

Awareness can be improved through education or training only. Youth, the future generation of nation is pursuing their higher education. These youth are educated or trained about how to tackle the global warming and climate change issues and motivated to be green in their approach of using ICT, so the natural World is in a position to be successful in Green Earth Mission followed by the sustenance of ICT. In spite of the initiatives, the factors that most significantly decide the execution of green ICT are motivation for adoption of GICT, user involvement, urgency to comply with government environmental laws and policies, top management and financial support, use of renewable energy. This paper is a step toward successful implementation of Green ICT practices and policies to eliminate environmental harms toward getting green environment. This study provides critical factors for successful implementation of Green ICT in education institution to achieve cost effectiveness and sustenance of ICT in future.

This research can be extended in future by doing quantitative analysis to measure the benefits of GICT by developing layered Green ICT Capability Maturity Model (GICTCMM) which constitutes base for the designing of metrics green tally cards and quantifies Green ICT implementation practices by use of these metrics. This would help the higher education institutions not only to determine the level of GICT implementation by using GICTCMM but also to take corrective measure to improve the level to attain maximum cost benefit analysis.

\section{REFERENCES}

[1] Managing the company's carbon footprint the emerging role of ICT, A report from Economist Intelligency Unit,Feb 2008, Online Available at www.graphics.eiu.com , [ Accessed 30 Nov 2013]

[2] Zacharoula Andreopoulou,E. Stiakakis and Maro Viachopoulou, "Green ICT Applications towards the Achievement of Sustainable Development", Chapter from Book Title : E-Innovation for Sustainable Development of Rural Resources During Global Economic Crisis , IGI Global,2014,pp 11-21.

[3] J.Porritt, "Green IT a Global Benchmark: a Report on Sustainable IT in the USA,UK,Australia and India",Fujitsu,Australia,2010. 
[4] Molla A., Vanessa C. Brain Corbitt, Hepu Deng, Say Yen Teoh, "E-Readiness to G-Readiness Developing a Green Information Technology Readiness Framework", 19th Australian Conference on Information Systems , 3-5 Dec 2008, Christchuch, Australia, o pp 669-678.

[5] Kallmorgen, J.-F. ,'Towards a Global Green Recovery Supporting Green Technology Markets", Atlantic Task Force Global Green Recovery, 2009.

[6] Suryawanshi K.,Narkhde S. ,"Evolution Of Green ICT Implementation At Education Institutions Study With Reference To Maharashtra", International Journal of Advanced Research in Engineering and Technology,ISSN $0976 \quad-6480$ (Print), ISSN 0976 - 6499(Online) Volume 4, Issue 6, September - October ,2013, pp 216-221.

[7] Supaporn Chai-Arayalert, Keiichi Nakata,"The Evolution of Green ICT Practice: UK Higher Education Institutions Case Study", IEEE International Conference on Green Computing and Communications, 2011, United Kingdom, pp 220-225.

[8] Suryawanshi K.,Narkhde S. "Evolution of Green ICT Implementation In Education Sector: A Study of Developed and Developing Country", International Journal of Management ,ISSN 0976 -6502(Print) ISSN 0976 - 6510(Online) Volume 4, Issue 2, March - April 2013, pp 91-98.

[9] Suryawanshi K.,Narkhde S. ,"Green ICT Implementation at Professional Education Institutions: A Study from Indian Context “, International Journal of Advanced Research in Computer Science and Electronics Engineering IJARCSEE ,Volume 1, Issue 8, Oct 2012, ISSN: $2277-9043$, pp 111-114.

[10] M. Riaz, José M., Jens, M. Pedersen, Strategies for the next generation green ICT infrastructure, $2^{\text {nd }}$ International Symposium on Applied Sciences in Biomedical and Communication Technologies, ISABEL, IEEE, 2010, Christchuch, Australia , pp 669-678.

[11] Molla A., " GITAM : A model for the Adoption of Green IT" , 19th Australian Conference on Information Systems, 3-5 Dec 2008 , Christchuch, Australia , pp 658-668.

[12] Mingay, "Green IT: The New Industry Shock Wave", Gartner, USA, 2007.

[13] San Murugesan, "Harnessing Green IT: Principals and Practices," IEEE IT Professional, January-February 2008, pp 24-33.

[14] Jussi Ahola, Toni Ahlqvist, Miikka Ermes, Jouko Mylly oja \& Juha Savola. ICT for Environmental Sustainability Green ICT Roadmap, 2010, VTT Tiedotteita - Research Notes 2532, $51 \mathrm{p}$.

[15] Cosmio Stallo, Mauro De Sanctis, Mario Marchese, ICT applications in Green and Renewable Energy Sector, 2010 Workshops on Enabling Technologies :Infrastructure for Collaborative Enterprises , IEEE,2010.

[16] Unhelkar, Trivedi, B., "A Framework of Environmentally Responsible Business Strategies. Green ICT; Technology, Business and Social Perspectives (Handbook)", USA: IGI Global,ISBN10: 1-61692-834-4, 2010, pp $214-233$
[17] C. Blurton," UNESCO's World Communication and Information Report", 1999,online Available at www.unesco.org, [Accessed 12 June 2011].

[18] Supaporn Chai-Arayalert, Keiichi Nakata, "The Evolution of Green ICT Practice: UK Higher Education Institutions Case Study", IEEE International Conference on Green Computing and Communications, 2011, United Kingdom, pp 220-225.

[19] Indonesia Green ICT Council Report, 2009 Online Available at www.jeita.or.jp [Accessed 12 June 2014]

[20] Albert Hankel , Green IT Practices in Dutch Higher Education, SURF net, 2013.

[21] Graeme Philipsan, "A Green ICT Framework Understanding and measuring Green ICT",Connection Research, Australia, April 2010.

[22] Tony Chan, "Inside the Australia Govt. ICT sustainability plan 2010-2015", posted in green telecom live newsletter, Australia, August 10, 2010.

[23] Asia- Pacific Economic Cooperation "Green Energy and Technology Issues and Challenges", Purpose Information Submitted by: Malaysia, 9th Energy Ministers Meeting, 18-20 June 2010, Fukui, Japan. Online available: www. mddb.apec.org [Accessed : 02 Nov. 2014]

[24] UGC Higher Education in India at a Glance - June, 2013 Online Availabe : www.ugc.ac.in [ Accessed :13 Dec. 2013].

[25] National Policy on ICT in School Education, Ministry of Human Resource Development , Government of India, 2010, Revised www.mhrd.gov.in.

[26] US publishes international energy statistics, Online available: www.eia.gov.in [Accessed : 15 Nov. 2013]

[27] Onkar Kendhe, "Basics of Green IT and India Perspective", CSI communications: Green computing Vol. No. 34, issue no. 10, Jan 2011 pp 11-15.

[28] Suryawanshi, K.; Narkhede, S., "Green ICT implementation at educational institution: A step towards sustainable future," Innovation and Technology in Education (MITE), 2013 IEEE International Conference in MOOC, 20-22 Dec. 2013

DOI: 10.1109/MITE.2013.6756344, pp.251-255.

[29] George Paul " E-waste Recycling Reuse and Disposal”, National Seminar on Green ICT - Empowering Rural India, Indian Institute of Information Technology, Allahabad ,India, 2010.

[30] Government of India ministry of Environment and Forests, "National mission for Green India", New Delhi, 26th March 2011, available at www.naeb.nic.in [Accessed :12 June 2014].

[31] Garnaik, S. P. 2011. "National Mission on Enhanced Energy Efficiency." New Delhi: Bureau of Energy Efficiency. Online Available at www.moef.nic.in [Accessed : 11 Oct. 2013]

[32] Agrawal, N.\& Agrawal , K.N., "Current Trends in Green ICT”, JOAAG, Vol. 7 ,No. 1 ,2012, pp 71-85.

[33] Directive 2011/65/Eu Of The European Parliament And Of The Council, Official Journal of the European Union, 2011, pp 174/88-174-110. Online Available at www.epeat.net [Accessed : 15 Dec. 2013] 